\title{
Management of University Electronic libraries in Northwest Nigeria
}

\author{
Gani Esther \\ (gani.estty@gmail.com) \\ Librarian I \\ Kaduna State University Library, Kaduna
}

\begin{abstract}
The study sets out to investigate the process of managing university e-libraries in Northwest zone of Nigerian. Issues of e-library management such as personnel, access to the e-library, computer usage, and registration of users, e-library resources and services were discussed. Objectives of this study include among others; who manages the e-library and how the e-libraries are managed. Four research questions among which are; who manages the e-library how are e-libraries managed in universities in Northwest zone of Nigerian are raised. Qualitative research method was adopted. Focus group method, eight (8) University Librarians (40) System librarians and System analysts from eight (8) universities in the Northwest of Nigeria were used as sample size of the study. Questionnaire constituted the instrument for data collection, while descriptive method was used to analyze the collected data. The findings of the study showed that the university librarian, system analyst and administrators are the managers of the e-libraries in Northwest zone of Nigeria and the finding also revealed that all the e-libraries in the Northwest zone are mostly funded by the Nigerian government. The universities e-libraries were opened between 8 to 12 hours daily and e-books, e-journals and online databases among others are the resources available in the e-libraries. The major challenges faced by the e-libraries under study were; IT literacy and infrastructure among others. The study concluded that universities should maintained highly trained staff to manage their e-libraries and avoid over dependence on government for funds, they should increase the e-library's opening hours in order to meet up with the ever growing information needs of library users in the Northwest Nigerian universities.
\end{abstract}

Keywords: Electronic library, Electronic Resources, ICT, IT, Management, Nigerian University,

\section{Introduction}

In the continent of Africa and Nigeria in particular is very rich with a lot of information resources that are useful for researches leading to a change in management of library system. The emergence of information and communication technology in the $21^{\text {st }}$ century has brought about a significant approach to the management of these resources in the academic environment through electronic libraries. Today information users prefer to use the electronic library via internet as primary sources of information, often relying on paper as the last resort due to the issue of distance and time. However the greatest challenge is the ability of libraries especially to those in the academic environment to manage these information resources and make them accessible to the universal scholarly community.

In Nigeria, is fast assuming the statue of an electronic library; a library which is made up of electronic materials and services including digitized and born digital resources, as well as other format of resources that need electricity gadgets to use such as video tapes, digital cameras and barcode sensors among others. As such the university library in Nigeria is charged with the responsibility of managing the resources through the elibrary to satisfy the ever increasing needs of the university community. Although the university libraries as a whole has not fully completely embraced the new technology, but there is an indication through the development of e-libraries which are utilized to manage the resources. Ojedokun (2011) noted that for university libraries in Nigeria, the pressure to go electronic has never been more visible and much more so in this era of globalization. As asserted by Ezema (2011) that Nigeria is accepting the e-library through information and communication technology in their day-by-day activities. However is also true that researches made in Nigeria are underutilized and that access to international resources is difficult. This is apparently because information resources from universities lack proper management which the e-library is out to tackle when the proper channel is put in place.

\section{Literature Review}

The e-library is being introduced to the library system worldwide because of the high value placed on the need, accessibility and availability of information. The increasing acceptance of the e-library might be due to 
the diverse materials that they contain. The option for what are available in an e-library are virtually endless, as well as becoming more and more boundless as technology advance. (Fabunmi, 2009).

E-library which stands for electronic library is synonymous with virtual and digital libraries. Issa et al (2009) confirmed that the term e-library is used synonymously with "digital", "universal", "future", "community", and "library without walls." It has been defined variously by different scholars depending on individual or organizational perspective. Ojedokun (2000) in his own perspective described the e-library as:

A collection of full text and bibliographic information source which incorporates human service (such as electronic publishing, personal management, and distance information use) and information technology tools (such as those to support browsing, author-ing and communication)

Aina (2004) defined Electronic library as a library that consist of materials and services in electronic formats rather than the print format. In his own view Shim et al (2001) defined Electronic library as those electronic information resources and services that users' access electronically via a computing network from inside the library or remote to the library. Electronic library resources are invaluable research tools which complement print-based resources in any traditional library; they provide access to information that might be restricted to the user because of geographical location or finances (Sabouri, et al 2010). The e-library (EL) most often referred to as digital library; virtual library and online library are not one and the same. The e-library most have a physical space holding ICT facilities of different types used for production, storage and dissemination of information. Users most often make themselves available in the e-library to access various resources.

According to Irokwe (2001), a digital library is a library that harnesses digital technologies as infrastructure to search, collect, organize, store and distribute cultural, historical and scientific information whether it is text, visual images or sound. This requires that all operations of the library are computerized. Such operations include selection and acquisition, cataloguing and classification etc, which comes into existence due to inconveniences of traditional library system. The digital library contains resources that are either born digital or digitized resources that pass through the process of transformation from hard to soft copies. It also developed electronic catalogue of all library materials, networking this catalogue, so that users not only in the library but also from elsewhere can access it within a particular community. Additionally, digital library includes the digitalization of locally produced information and the establishment of institutional repositories, to provide access to the scholarly material produced by members of the user community. Hence when a digital library is launched into the Internet where resources are accessed universally it is then said to become virtual in nature.

According to Daniel (2002), Nancy Schiller was one of the first writers to use the expression "virtual". Schiller simply uses the term as "libraries in which computer and telecommunication technologies make access to a wide range of information resources possible." All virtual libraries must, by virtue, be electronic, but not all electronic libraries are necessarily virtual. It is called 'virtual' because in a good electronic wide area networked library, the user enjoys the euphoria of being able to access collections in distant libraries, and yet he has not physically moved. It is an experience of virtual reality; the user does not need to be in a library environment or be member of the user community. Fabunmi (2009) added more light that the virtual library can consist of materials from a variety of separate libraries that are organized in a virtual space using computers and computer networks. Virtual library is a collection of machine readable documents made available through an Internet site. The library does not exist in real life because physically it is not accessible but then it exists. Powell (1994) defined VL as: "a library with little or no physical presence of books, periodicals, reading space, or support staff, that disseminates selective information directly to distributed library customers, usually electronically."

Despite the differences enumerated above, Fabunmi (2009) and Irokwe (2001) see e-library as synonymous to digital and virtual Library. Both noted that a library having digital collections that could be accessed universally can be referred to as being virtual while a library with all holdings on CD-Roms, DVDRoms, FMD-Roms, etc. accessed from stand-alone computers would be electronic which leads to the digital or virtual environment.

What is being referred to as e-library in Nigerian is known as information commons in advanced countries of the world, because information commons refers to a physical space usually in an academic library environment, where any and all can participate in the process of information research, gathering and production. Beagle, (1999) explained that the information commons is a conceptual, physical and instructional space that involves an organizational realignment from print to the digital environment characterized by having Pervasive technology, group spaces, work stations and user services not just information services. And this shows that the e-library and information commons share the same nature and characteristics because both deal with the combination of both physical and virtual spaces. It is also important to note that it is the e-library that 
gives the opportunity to venture in the virtual space. The e-library contains the physical technologies that enable the virtual technology to perform. Also access to the virtual space is made real through the e-library.

The fundamental role and services of libraries are permanently changing as a result of advances in electronic and communication technologies. Based on this, electronic library if properly managed can offer many advantages to libraries as well as their users. They are capable of handling and overcoming deficiencies and challenges faced by the conventional libraries in numerous ways. Kumar (2007) defined management as a "process of coordinating the total resources of an organization through the execution of a group of interrelated functions such as planning, organizing, staffing, directing and controlling."

Managing the e-library in a university environment can be seen as a new role for librarians in Nigerian universities. It is a strategically important activity with many practical implications for university library management. Also, it entails putting together practical aspect of managing the e-library for effective performance in the university library. Okpara (2004) agrees to it when he stated that "all management functions - planning, organizing, controlling and directing are necessary for effective running of the e-library." Oyelude (2004) advocated that e-library management should be made up of a technical work group that sets up and prevents underutilization of IT facilities and resources in the e-library. They should be mandated to establish the e-library, encourage and instill culture of computer literacy, emphasize hands-on experience and keeping abreast of the latest IT literatures. Batool and Ameen (2010) Identified technological core competency of library personnel to effectively manage the e-library. They added that "skills, knowledge and behavior related to library technology and are important for organization success, personnel performance in the e-library.

Aina (2008) mentioned the following strategies on how best to manage an e-library: law, policies and procedures, staff and training and storage and accessibility of e-library resources. Bar- Ilan and Fink (2005) in their survey on e-library users show that if the e-library is well manage it will lead to: Increases of e-library resources with time; There is a gradual reduction in the use of printed journals as users prefer and use the electronic format more; Users access the electronic format more frequently; There may be an increase in the acceptance and frequency of use of the electronic format merely because the traditional print format is no longer easily available.

The level of e-library acceptance in Nigeria universities can be said to be of very high level. However, Nigerian universities are challenged by the trends in the global digital society which are associated with the use of ICTs. Mutula (2008) discussed in details and listed the following factors affecting e-library management in third world countries: Lack of access to electricity and telephone, illiteracy and limited skills, language barriers, low technological penetration, low PC density, lack of content developers and lack of appropriate policies. Also Woherem (2000) identified the following major problems facing ICT based libraries which includes: system downtimes, lack of knowledge to develop internal IT and IT management skills, lack of internal maintenance skill culture, lack of IT strategies, the gimmicks of vendors, lack of basic infrastructure and facilities, lack of maintenance culture and unhelpful government policies. Ayo (2001) identified the setbacks to Internet as, power failure, telephone, illiteracy, poverty, lack of adequate man power, insecurity and virus attack. In conclusion, more challenges faced in Nigerian universities are some natural disasters such as fire outbreaks and flood just like that of Usmanu Danfadio University which was affected by flooded in year 2011.

This review established the importance of managing electronic libraries for effective and efficient library and information service delivery. Conclusively, university libraries in Northwest zone of Nigeria need to manage their electronic libraries in other to meet with global challenges.

\section{Statement of the Problem}

The act of classical librarianship is becoming tedious and cumbersome as time goes on due to the increase in information demand. Also, the days whereby big building and housing a large collection as a matter value to the library is over. Today, ICTs have revolutionized the classical library system which led to the phenomenon of establishing e-libraries in universities. The emergence and convergence of ICT remains the centre of global and social economic transformation Emwanta (2012).

The management of the e-libraries in Nigerian universities has given the library a prestigious role of producing and disseminating information. Most resources in the universities are not made visible in the global scenes but rather buried within their specific universities due to lack of management strategies through the elibraries to promote these resources. The greatest challenge in the university libraries is that several researches made are either disseminated in expensive foreign journals of kept in remote places where they are underutilized. Lack of proper management of the e-libraries affects the production and utilization of the eresources in Nigerian universities Moahi (2009). The university e-libraries on a daily basis need proper management to improve their visibility and impact within Nigeria and globally. 
The researcher observed that the e-library life span is short; this could be attributed to the fact that they are not adequately managed, maintained and staffed. As observed by Gbaje (2007), some of these e-libraries are affected by the absence of basic information infrastructure, poor policy implementation, and lack of web technologies/systems librarians amongst others. Could it be that there are not properly managed? Could it be that the libraries are underfunded? Could it be that the staff in the e-library are not competent enough to manage the affairs of the e-libraries?

Since the e-library in Nigerian universities enhances effective and efficient information service delivery within the university and globally, the researcher intends to assess the management of e-libraries in universities so that factors that hinders effective utilization of the e-libraries be tackled. Though most universities in Northwest Nigeria have viable e-libraries, the major concern of the paper has provided answers to the following questions:

1. Who are the personnel that manage the university e-libraries in Northwest of Nigerian?

2. How is the university e-libraries funded in Northwest of Nigerian?

3. What equipments are used in managing the university e-libraries in Northwest of Nigerian?

4. What are the challenges of managing the universities e-libraries in Northwest of Nigerian?

\section{Methodology}

The study adopted qualitative methodology approach. Crewell (2003) defined qualitative research as that research which takes place in the natural setting in which the researcher often goes to the site (office) of the participant to conduct the research. Silverman (2011) explained that qualitative research aims at gaining a deep understanding of a specific organization rather than surface description of a large population. Population of the study consists of all university libraries in Northwest Zone of Nigeria who are on the approved list of universities in Nigeria by Nigerian University Commission (NUC) and have functional e-libraries. They are Ahmadu Bello University, Zaria, Kaduna State; Bayero University Library, Kano, Kano State; Nigerian Defence Academy, Kaduna, Kaduna; Usmanu Fadiyo University, Sokoto, Sokoto state; The four state university libraries are: Kaduna State University Library, Kaduna, Kaduna State; Umaru Musa University, Katsina, Katsina State; Kano University of Technology, Wudil, Kano State; Kebbi State University of Science and Technology, Alero, Kebbi State.

The target population of 48 staff of the above listed university libraries in Northwest zone of Nigeria who were purposely selected. They are made up of the 8 senior management of the university library (University Librarian) and 40 staff of the e-library in the universities. The researcher used questionnaire as the instruments for collecting data considering the nature and predisposition of the respondents. It helps to keep the respondent's mind fixed to the subject and facilitate the process of research generalization. The data collected was analyzed descriptively.

\section{Findings and Discussion}

Response Rate: There was a high response rate from the sampled staff of the e-libraries in Northwest universities of Nigeria who filled the questionnaire. A response rate of $95.83 \%$ was achieved. Table 4.1 shows the response rate.

Table 1: Response Rate

\begin{tabular}{|c|c|c|c|c|}
\hline $\mathbf{S} / \mathbf{N}$ & University Library & Category & Sample Size & Response Rate \\
\hline \multirow[t]{2}{*}{1} & \multirow{2}{*}{$\begin{array}{l}\text { Kashim Ibrahim Library, Ahmadu Bello University, } \\
\text { Zaria. Kaduna State. }\end{array}$} & University Librarian & 1 & 1 \\
\hline & & Staff of the e-library & 5 & 5 \\
\hline \multirow[t]{2}{*}{2} & \multirow[t]{2}{*}{ Bayero University Library, Kano, Kano State. } & University Librarian & 1 & 1 \\
\hline & & Staff of the e-library & 5 & 5 \\
\hline \multirow[t]{2}{*}{3} & \multirow{2}{*}{$\begin{array}{l}\text { Abdulahi Fadiyo Library, Usmanu } \\
\text { University, Sokoto, Sokoto State. }\end{array}$} & University Librarian & 1 & 1 \\
\hline & & Staff of the e-library & 5 & 5 \\
\hline \multirow[t]{2}{*}{4} & \multirow{2}{*}{$\begin{array}{l}\text { Nigerian Defence Academy Library, Kaduna, Kaduna } \\
\text { State }\end{array}$} & University Librarian & 1 & 1 \\
\hline & & Staff of the e-library & 5 & 5 \\
\hline \multirow[t]{2}{*}{5} & \multirow{2}{*}{$\begin{array}{l}\text { Kaduna State University Library, Kaduna, Kaduna } \\
\text { State }\end{array}$} & University Librarian & 1 & 1 \\
\hline & & Staff of the e-library & 5 & 5 \\
\hline \multirow[t]{2}{*}{6} & \multirow{2}{*}{$\begin{array}{l}\text { Kano State University of Technology Library, Wudil, } \\
\text { Kano State. }\end{array}$} & University Librarian & 1 & 1 \\
\hline & & Staff of the e-library & 5 & 4 \\
\hline \multirow[t]{2}{*}{7} & \multirow{2}{*}{$\begin{array}{l}\text { Umaru Musa Yar'adua University Library, Katsina, } \\
\text { Katsina State }\end{array}$} & University Librarian & 1 & 1 \\
\hline & & Staff of the e-library & 5 & 5 \\
\hline \multirow[t]{2}{*}{8} & \multirow[t]{2}{*}{ Kebbi State University Library, Aliero. Kebbi State } & University Librarian & 1 & 1 \\
\hline & & Staff of the e-library & 5 & 4 \\
\hline \multicolumn{2}{|c|}{ Total } & & 48 & 46 \\
\hline
\end{tabular}

A ninety five point eighty three percent response rate was achieved for the structured and semistructured focus group interviews. This high response rate was achieved because of the fact that the population was very small. The researcher had to formally seek for permission from the university librarians in all the 
university under study, who implored the staff of the e-libraries to give the researcher all the necessary support and cooperation in the data collection exercise.

\section{Data Analysis and Discussion}

The research question in the study, which is to find out how e-libraries were managed in universities in the Northwest zone Nigeria was formulated in order to find out management issues such as personnel, funding, method of organizing e-library resources, access to e-resources, services provided, storage of equipment and challenges of the e-libraries. The first research question was to find out the personnel that manages the elibraries. The detail of the findings is on Table 2 .

Table 2: $\quad$ Personnel that manages the E-libraries

\begin{tabular}{|l|c|c|c|}
\hline & \multicolumn{2}{|c|}{ Personnel that manages the e-libraries } \\
\hline Universities Libraries & $\begin{array}{c}\text { University } \\
\text { Librarian }\end{array}$ & $\begin{array}{l}\text { System } \\
\text { libraria } \\
\text { n }\end{array}$ & $\begin{array}{c}\text { System Analyst/ } \\
\text { Administrators }\end{array}$ \\
\hline $\begin{array}{l}\text { Kashim Ibrahim Library, Ahmadu Bello University, Zaria. Kaduna } \\
\text { State. }\end{array}$ & $\checkmark$ & $\checkmark$ & $\checkmark$ \\
\hline Bayero University Library, Kano, Kano State. & $\checkmark$ & $\checkmark$ & $\checkmark$ \\
\hline $\begin{array}{l}\text { Abdulahi Fadiyo Library, Usmanu Danfodiyo University, Sokoto, } \\
\text { Sokoto State. }\end{array}$ & $\checkmark$ & $\checkmark$ & $\checkmark$ \\
\hline Nigerian Defence Academy Library, Kaduna, Kaduna State & $\checkmark$ & $\checkmark$ & $\checkmark$ \\
\hline Kaduna State University Library, Kaduna, Kaduna State. & $\checkmark$ & $\checkmark$ & $\checkmark$ \\
\hline Kano State University of Technology Library, Wudil, Kano State. & $\checkmark$ & $\checkmark$ & $\checkmark$ \\
\hline Umaru Musa Yar'adua University Library, Katsina, Katsina State. & $\checkmark$ & $\checkmark$ & $\checkmark$ \\
\hline Kebbi State University Library, Aliero. Kebbi State & $\checkmark$ & $\checkmark$ & $\checkmark$ \\
\hline
\end{tabular}

Key: $\quad \sqrt{=}$ Applicable $\quad \mathrm{X}=$ Not Applicable

The finding on Table 2 shows that the University Librarian, system librarians and system analyst were the categories of staff who manage the e-library. The significance of the result proves that they were the managers and key players in the running of the day-to-day activities for successful management of their elibraries. The inclusion of the university librarians implies that they are the leaders in decision making and not in the implementation stage.

Table 3: Funding of E-Libraries

\begin{tabular}{|c|c|c|c|c|}
\hline \multirow[b]{2}{*}{ Universities Libraries } & \multicolumn{3}{|c|}{ How E-Libraries are Funded } & \multirow[b]{2}{*}{ Total } \\
\hline & $\begin{array}{c}\text { Through } \\
\text { Appropriation } \\
\text { from the Govt }\end{array}$ & $\begin{array}{c}\text { Internally } \\
\text { Generated } \\
\text { Funds }\end{array}$ & TETfund & \\
\hline $\begin{array}{l}\text { Kashim Ibrahim Library, Ahmadu Bello University, } \\
\text { Zaria. Kaduna State. }\end{array}$ & $\checkmark$ & $\checkmark$ & $\checkmark$ & \\
\hline Bayero University Library, Kano, Kano State. & $\checkmark$ & $\mathrm{X}$ & $\checkmark$ & \\
\hline $\begin{array}{lccc}\text { Abdulahi Fadiyo Library, } & \text { Usmanu } & \text { Danfodiyo } \\
\text { University, Sokoto, Sokoto State. } & & \\
\end{array}$ & $\checkmark$ & $\mathrm{X}$ & $\checkmark$ & \\
\hline $\begin{array}{l}\text { Nigerian Defence Academy Library, Kaduna, Kaduna } \\
\text { State }\end{array}$ & $\checkmark$ & $\mathrm{X}$ & $\checkmark$ & \\
\hline Kaduna State University Library, Kaduna, Kaduna State. & $\checkmark$ & $\mathrm{X}$ & $\checkmark$ & \\
\hline $\begin{array}{l}\text { Kano State University of Technology Library, Wudil, } \\
\text { Kano State. }\end{array}$ & $\checkmark$ & $\mathrm{X}$ & $\checkmark$ & \\
\hline $\begin{array}{l}\text { Umaru Musa Yar'adua University Library, Katsina, } \\
\text { Katsina State. }\end{array}$ & $\checkmark$ & $\mathrm{X}$ & $\checkmark$ & \\
\hline Kebbi State University Library, Aliero. Kebbi State & $\checkmark$ & $\mathrm{X}$ & $\checkmark$ & \\
\hline
\end{tabular}

Key: $\quad \sqrt{ }=$ Applicable $\quad \mathrm{X}=$ Not Applicable

Table 3 reveals that all universities indicated that they were being funded by the government and TETfund in Northwest zone Nigeria. Only KIL of ABU indicated that, apart from TETfund and the government, its uses it internally generated funds for the e-library. The finding implies that universities depend mostly on the government for finances.

Table 4:E-libraries opening hours

\begin{tabular}{|l|l|l|c|c|c|c|c|c|}
\hline \multirow{2}{*}{$\begin{array}{l}\text { E-library opening } \\
\text { hours }\end{array}$} & Fed Universities & \multicolumn{3}{l|}{ State Universities } \\
\cline { 2 - 9 } & KIL & BUK & ADL & NDA & KASU & UMYU & KSUT & KBUT \\
\hline 24/7 every day & X & X & X & X & X & X & X & X \\
\hline 12 hours daily & $\checkmark$ & $\checkmark$ & $\checkmark$ & $\checkmark$ & X & X & X & X \\
\hline 8 hours daily & X & X & X & X & $\checkmark$ & $\checkmark$ & $\checkmark$ & $\checkmark$ \\
\hline
\end{tabular}

$$
=\text { Applicable } \quad \mathrm{X}=\text { Not Applicable }
$$


Table 5 indicated that four universities open their e-libraries for 12 hours daily while the others indicated 8 hours. The implication of the result could be that the universities that open for longer hours have more population of users, so they open their e-libraries for half a day so as to meet the needs of such users. Also lack of opening for 24/7 hours affects the optimum utilization of the e-library facilities. The non indication of their e-library opening for 24/7 is in line with Ekoja (2011) who stated that this service already exists in many parts of the world but it is gradually coming into our Nigerian practice. Therefore, it could be concluded from the above data that most universities in Northwest of Nigeria open their e-libraries for 8 hours on daily basis.

Table 5: Access to Computers in the E-Library

\begin{tabular}{|c|c|c|c|c|}
\hline \multirow[b]{2}{*}{ Universities Libraries } & \multicolumn{4}{|c|}{ Users Access to Computers } \\
\hline & Directly & $\begin{array}{c}\text { Through } \\
\text { Library } \\
\text { Assistant }\end{array}$ & $\begin{array}{c}\text { Through } \\
\text { System } \\
\text { Analyst }\end{array}$ & $\begin{array}{l}\text { Any } \\
\text { Other }\end{array}$ \\
\hline $\begin{array}{l}\text { Kashim Ibrahim Library, Ahmadu Bello University, Zaria. } \\
\text { Kaduna State. }\end{array}$ & $\mathrm{X}$ & $\checkmark$ & $\sqrt{ }$ & $\mathrm{X}$ \\
\hline Bayero University Library, Kano, Kano State. & $\mathrm{X}$ & $\checkmark$ & $\checkmark$ & $\mathrm{X}$ \\
\hline $\begin{array}{l}\text { Abdulahi Fadiyo Library, Usmanu Danfodiyo University, } \\
\text { Sokoto, Sokoto State. }\end{array}$ & $\mathrm{X}$ & $\checkmark$ & $\checkmark$ & $\mathrm{X}$ \\
\hline Nigerian Defence Academy Library, Kaduna, Kaduna State & $\mathrm{X}$ & $\checkmark$ & $\checkmark$ & $\mathrm{X}$ \\
\hline Kaduna State University Library, Kaduna, Kaduna State. & $\mathrm{X}$ & $\checkmark$ & $\checkmark$ & $\mathrm{X}$ \\
\hline $\begin{array}{l}\text { Kano State University of Technology Library, Wudil, Kano } \\
\text { State. }\end{array}$ & $\mathrm{X}$ & $\checkmark$ & $\checkmark$ & $\mathrm{X}$ \\
\hline $\begin{array}{l}\text { Umaru Musa Yar'adua University Library, Katsina, } \\
\text { Katsina State. }\end{array}$ & $\mathrm{X}$ & $\checkmark$ & $\checkmark$ & $\mathrm{X}$ \\
\hline Kebbi State University Library, Aliero. Kebbi State & $\mathrm{X}$ & $\checkmark$ & $\checkmark$ & $\mathrm{X}$ \\
\hline
\end{tabular}

Key: $\quad \sqrt{ }=$ Applicable $\quad \mathrm{X}=$ Not Applicable

Table 5 reveals that e-library users in Northwest zone of Nigerian universities get access to the computers in their e-libraries through the library assistant and system analyst. A close look at the findings indicates that the system librarian and analyst who are the major staff in their e-libraries have as one of their major responsibility to assist users in using the computers in their e-libraries. This implies that some e-library users may not be advanced in computer application, they therefore need to assist these non computer literate users. With such assistance render users will the encouraged to access e-resources and there will be a high increase in information production and utilization. This finding agrees with Mabawonku (2009) who stated that ICT is gradually taking its root in Nigerian Universities; therefore, e-library users also need some guidance and assistance on how to use the computers and other e-library accessories.

Table 6:

Time Allocation to Users

\begin{tabular}{|c|c|c|c|c|c|c|c|c|}
\hline \multirow[t]{2}{*}{ Timing of Users } & \multicolumn{4}{|c|}{ Fed Universities } & \multicolumn{4}{|c|}{ State Universities } \\
\hline & KIL & BUK & UDUS & NDA & KASU & UMYU & KSUT & KBUT \\
\hline 2 hours daily per student & $\checkmark$ & $\checkmark$ & $\checkmark$ & $\mathrm{X}$ & $\checkmark$ & $\checkmark$ & $\checkmark$ & $\checkmark$ \\
\hline 3 hours daily per student & $\mathrm{X}$ & $\mathrm{X}$ & $\mathrm{X}$ & $\mathrm{X}$ & $\mathrm{X}$ & $\mathrm{X}$ & $\mathrm{X}$ & $\mathrm{X}$ \\
\hline 3 hours daily per staff & $\mathrm{X}$ & $\mathrm{X}$ & $\mathrm{X}$ & $\mathrm{X}$ & $\mathrm{X}$ & $\mathrm{X}$ & $\mathrm{X}$ & $\mathrm{X}$ \\
\hline 4 hours daily per staff & $\mathrm{X}$ & $\mathrm{X}$ & $\mathrm{X}$ & $\mathrm{X}$ & $\mathrm{X}$ & $\mathrm{X}$ & $\mathrm{X}$ & $\mathrm{X}$ \\
\hline Unlimited access to staff & $\checkmark$ & $\checkmark$ & $\checkmark$ & $\checkmark$ & $\checkmark$ & $\checkmark$ & $\checkmark$ & $\checkmark$ \\
\hline
\end{tabular}

Key: $\quad \sqrt{ }=$ Applicable

$\mathrm{X}=$ Not Applicable

In table 7 it can be observed that apart from NDA that indicated unlimited allocation of time to its staff and student, all other libraries indicated 2 hours each per student and unlimited time for staff. The implication of this may be due to the fact that staff are engaged in study, teaching and research activities and so they needed more time to achieve that objective in universities in Northwest zone of Nigerian.

Table 7: Resources Accessible to Users of E-library in Nigerian Universities

\begin{tabular}{|c|c|c|c|c|c|c|c|c|c|}
\hline \multirow[t]{2}{*}{ E-Resources } & \multicolumn{4}{|c|}{ Fed Universities } & \multicolumn{4}{|c|}{ State Universities } & \multirow[b]{2}{*}{ Total } \\
\hline & KIL & BUK & $\begin{array}{l}\text { UDU } \\
\text { S }\end{array}$ & NDA & KASU & UMYU & KSUT & KBUT & \\
\hline E-books & $\checkmark$ & $\checkmark$ & $\checkmark$ & $\checkmark$ & $\checkmark$ & $\checkmark$ & $\checkmark$ & $\checkmark$ & 8 \\
\hline E-Journals & $\checkmark$ & $\checkmark$ & $\checkmark$ & $\checkmark$ & $\checkmark$ & $\checkmark$ & $\checkmark$ & $\checkmark$ & 8 \\
\hline E-dissertations & $\checkmark$ & $\checkmark$ & $\checkmark$ & $\checkmark$ & $\checkmark$ & $\checkmark$ & $\checkmark$ & $\checkmark$ & 8 \\
\hline CD-ROM Searching service & $\checkmark$ & $\checkmark$ & $\checkmark$ & $\checkmark$ & $\checkmark$ & $\checkmark$ & $\checkmark$ & $\checkmark$ & 8 \\
\hline On-line databases & $\checkmark$ & $\checkmark$ & $\checkmark$ & $\checkmark$ & $\checkmark$ & $\checkmark$ & $\checkmark$ & $\checkmark$ & 8 \\
\hline $\begin{array}{l}\text { Online public access catalogs } \\
\text { (OPAC) }\end{array}$ & $\checkmark$ & $\checkmark$ & $\checkmark$ & $\checkmark$ & $\checkmark$ & $\checkmark$ & $\checkmark$ & $\checkmark$ & 8 \\
\hline
\end{tabular}


Management of University Electronic library in Northwest Zone of Nigerian Universities

\begin{tabular}{|c|c|c|c|c|c|c|c|c|c|}
\hline Full- text databases & $\checkmark$ & $\checkmark$ & $\checkmark$ & $\checkmark$ & $\checkmark$ & $\checkmark$ & $\checkmark$ & $\checkmark$ & 8 \\
\hline Scholarly websites & $\checkmark$ & $\checkmark$ & $\checkmark$ & $\checkmark$ & $\checkmark$ & $\checkmark$ & $\checkmark$ & $\checkmark$ & 8 \\
\hline Pre-print archives & $\mathrm{X}$ & $\mathrm{X}$ & $\mathrm{X}$ & $\mathrm{X}$ & $\mathrm{X}$ & $\mathrm{X}$ & $\bar{X}$ & $\mathrm{X}$ & 0 \\
\hline Bulletin boards & $\mathrm{X}$ & $\mathrm{X}$ & $\mathrm{X}$ & $\mathrm{X}$ & $\mathrm{X}$ & $\mathrm{X}$ & $\mathrm{X}$ & $\mathrm{X}$ & 0 \\
\hline Almanacs & $\checkmark$ & $\checkmark$ & $\checkmark$ & $\checkmark$ & $\checkmark$ & $\checkmark$ & $\checkmark$ & $\checkmark$ & 8 \\
\hline Bibliographies & $\checkmark$ & $\checkmark$ & $\checkmark$ & $\checkmark$ & $\checkmark$ & $\checkmark$ & $\checkmark$ & $\checkmark$ & 8 \\
\hline Directories & $\checkmark$ & $\checkmark$ & $\checkmark$ & $\checkmark$ & $\checkmark$ & $\mathrm{X}$ & $\bar{X}$ & $\mathrm{X}$ & 5 \\
\hline Institutional Repository & $\checkmark$ & $\checkmark$ & $\checkmark$ & $\checkmark$ & $\mathrm{X}$ & $\mathrm{X}$ & $\mathrm{X}$ & $\mathrm{X}$ & 4 \\
\hline
\end{tabular}

Key:

$\sqrt{ }=$ Available

$\mathrm{X}=$ Not Available

In Table 7, the respondents indicated that e-books, e-journal, e-dissertations, CD-ROM searching, OPAC, scholarly websites bulletin board, almanacs are accessible in all the university e-libraries in Northwest zone Nigeria. Closer looks at the table reveal that pre-print achieves and bulletin boards are not accessible in Northwest Nigerian University e-libraries which implies that despite the importance attach to e-resources for effective management of the e-libraries; some of the resources listed above are not made accessible to the e-library users.

The above findings agree with the assertion of Anonubi \& Okoye (2008) that "despite the availability of ICTs in Nigerian libraries, to enhance the access to e-library resources; some librarians are not sure of the existence of such e-resources. This is amazing because base on the awareness of ICTs in university libraries accessing such resources should not be a problem.

Table 8: Devices Used in Storing E-library Resources

\begin{tabular}{|c|c|c|c|c|c|c|c|c|}
\hline & \multicolumn{8}{|c|}{ E-library Storage Devices } \\
\hline Universities Libraries & $\begin{array}{l}\text { Floppy } \\
\text { Disk }\end{array}$ & CD & DVD & $\begin{array}{l}\text { Magnet } \\
\text { Tapes }\end{array}$ & $\begin{array}{l}\text { Flash } \\
\text { Drive }\end{array}$ & $\begin{array}{l}\text { Memory Hard } \\
\text { drives }\end{array}$ & $\begin{array}{l}\text { External } \\
\text { Hard Drive }\end{array}$ & $\begin{array}{l}\text { Cloud } \\
\text { Computing }\end{array}$ \\
\hline $\begin{array}{l}\text { Kashim Ibrahim Library, Ahmadu } \\
\text { Bello University, Zaria. Kaduna } \\
\text { State. }\end{array}$ & $\mathrm{X}$ & $\sqrt{ }$ & $\checkmark$ & $\mathrm{X}$ & $\mathrm{X}$ & $\sqrt{ }$ & $\checkmark$ & $\mathrm{X}$ \\
\hline $\begin{array}{l}\text { Bayero University Library, Kano, } \\
\text { Kano State. }\end{array}$ & $\mathrm{X}$ & $\sqrt{ }$ & $\checkmark$ & $\mathrm{X}$ & $\checkmark$ & $\checkmark$ & $\checkmark$ & $\mathrm{X}$ \\
\hline $\begin{array}{l}\text { Abdulahi Fadiyo Library, Usmanu } \\
\text { Danfodiyo University, Sokoto, } \\
\text { Sokoto State. }\end{array}$ & $\checkmark$ & $\sqrt{7}$ & $\checkmark$ & $\mathrm{X}$ & $\checkmark$ & $\checkmark$ & $\checkmark$ & $\mathrm{X}$ \\
\hline $\begin{array}{l}\text { Nigerian Defence Academy } \\
\text { Library, Kaduna, Kaduna State }\end{array}$ & $\checkmark$ & $\sqrt{ }$ & $\checkmark$ & $\mathrm{X}$ & $\checkmark$ & $\checkmark$ & $\checkmark$ & $\mathrm{X}$ \\
\hline $\begin{array}{l}\text { Kaduna State University Library, } \\
\text { Kaduna, Kaduna State. }\end{array}$ & $\mathrm{X}$ & $\sqrt{ }$ & $\checkmark$ & $\bar{X}$ & $\checkmark$ & $\checkmark$ & $\checkmark$ & $\mathrm{X}$ \\
\hline $\begin{array}{l}\text { Kano State University of } \\
\text { Technology Library, Wudil, Kano } \\
\text { State. }\end{array}$ & $\checkmark$ & $\sqrt{7}$ & $\checkmark$ & $\mathrm{X}$ & $\checkmark$ & $\checkmark$ & $\checkmark$ & $\mathrm{X}$ \\
\hline $\begin{array}{l}\text { Umaru Musa Yar'adua University } \\
\text { Library, Katsina, Katsina State. }\end{array}$ & $\mathrm{X}$ & $\sqrt{7}$ & $\checkmark$ & $\mathrm{X}$ & $\checkmark$ & $\checkmark$ & $\checkmark$ & $\mathrm{X}$ \\
\hline $\begin{array}{l}\text { Kebbi State University Library, } \\
\text { Aliero. Kebbi State }\end{array}$ & $\checkmark$ & $\sqrt{ }$ & $\checkmark$ & $\mathrm{X}$ & $\checkmark$ & $\checkmark$ & $\checkmark$ & $\mathrm{X}$ \\
\hline
\end{tabular}

\section{Key: $\quad \sqrt{=}$ Applicable $\quad \mathrm{X}=$ Not Applicable}

In Table 8, no university indicated using magnetic tapes and cloud computing in organizing the eresources. This may be due to the fact that these technologies might be too advanced or they had not yet acquired them in the e-libraries under study. The implication of this is that the e-libraries in Northwest zone of Nigeria might not be able to perform like their counterparts in other parts on the country or world.

Table 9:

Services Offered in the E-libraries

\begin{tabular}{|c|c|c|c|c|c|c|c|c|}
\hline \multirow[t]{2}{*}{ Types of services } & \multicolumn{4}{|c|}{ Fed Universities } & \multicolumn{4}{|c|}{ State Universities } \\
\hline & KIL & BUK & UDUS & NDA & KASU & UMYU & KSUT & KBUT \\
\hline Network Services & $\checkmark$ & $\checkmark$ & $\checkmark$ & $\checkmark$ & $\checkmark$ & $\checkmark$ & $\checkmark$ & $\checkmark$ \\
\hline Virtual Reference Service & $\mathrm{X}$ & $\mathrm{X}$ & $\mathrm{X}$ & $\mathrm{X}$ & $\mathrm{X}$ & $\mathrm{X}$ & $\mathrm{X}$ & $\mathrm{X}$ \\
\hline Student Help Desk & $\checkmark$ & $\checkmark$ & $\checkmark$ & $\checkmark$ & $\checkmark$ & $\checkmark$ & $\checkmark$ & $\checkmark$ \\
\hline Tech. Help Desk & $\checkmark$ & $\checkmark$ & $\checkmark$ & $\checkmark$ & $\checkmark$ & $\checkmark$ & $\checkmark$ & $\checkmark$ \\
\hline $\begin{array}{lll}\text { Support } & \text { Service } & \text { for } \\
\text { Teaching } & & \\
\end{array}$ & $\checkmark$ & $\checkmark$ & $\checkmark$ & $\checkmark$ & $\checkmark$ & $\checkmark$ & $\checkmark$ & $\checkmark$ \\
\hline $\begin{array}{l}\text { Ethernet Port and Docking } \\
\text { Station }\end{array}$ & $\mathrm{X}$ & $\checkmark$ & $\mathrm{X}$ & $\checkmark$ & $\bar{X}$ & $\mathrm{X}$ & $\mathrm{X}$ & $\mathrm{X}$ \\
\hline Reprographic services & $\checkmark$ & $\checkmark$ & $\checkmark$ & $\checkmark$ & $\checkmark$ & $\checkmark$ & $\checkmark$ & $\sqrt{ }$ \\
\hline Video and Audio Recording & $\checkmark$ & $\checkmark$ & $\checkmark$ & $\sqrt{ }$ & $\checkmark$ & $\checkmark$ & $\mathrm{X}$ & $\mathrm{X}$ \\
\hline Printing Service & $\checkmark$ & $\checkmark$ & $\checkmark$ & $\checkmark$ & $\checkmark$ & $\checkmark$ & $\checkmark$ & $\checkmark$ \\
\hline
\end{tabular}


From the data presented on Table 9, it is glaring that out of the eleven services provided in the course of managing the e-libraries in Northwest zone of Nigerian universities, network services, support services for teaching, student and technology help desk were services provided for managing e-libraries. A closer look at the table also revealed that reprographic services such as video and audio recordings were also services provided in the e-libraries. No library indicated the provision of virtual reference services in the course of managing their elibraries.

The indication of the finding that no respondent indicated that their e-library offers virtual reference services is in line with Ekoja (2011) who asserted that asserts this service is provided in some parts of the world the practice is just coming into most third world countries like Nigeria. Therefore, it could be concluded from the above data that most universities in Northwest zone in Nigeria had not started the virtual library services.

Table 10: $\quad$ Challenges of E-Libraries in Northwest Universities of Nigeria

\begin{tabular}{|c|c|c|c|c|c|c|c|c|c|}
\hline \multirow{2}{*}{$\begin{array}{l}\text { Management } \\
\text { Challenges }\end{array}$} & \multicolumn{4}{|c|}{ Fed Universities } & \multicolumn{4}{|c|}{ State Universities } & \multirow[b]{2}{*}{ Total } \\
\hline & KIL & BUK & ADL & NDA & KASU & UMYU & KSUT & KBUT & \\
\hline Funding & $\checkmark$ & $\checkmark$ & $\checkmark$ & $\checkmark$ & $\checkmark$ & $\checkmark$ & $\checkmark$ & $\checkmark$ & 8 \\
\hline Technology & $\checkmark$ & $\checkmark$ & $\checkmark$ & $\checkmark$ & $\checkmark$ & $\checkmark$ & $\checkmark$ & $\checkmark$ & 8 \\
\hline Infrastructure & $\mathrm{X}$ & $\mathrm{X}$ & $\mathrm{X}$ & $\mathrm{X}$ & $\checkmark$ & $\checkmark$ & $\checkmark$ & $\checkmark$ & 4 \\
\hline Security & $\mathrm{X}$ & $\mathrm{X}$ & $\mathrm{X}$ & $\mathrm{X}$ & $\mathrm{X}$ & $\mathrm{X}$ & $\mathrm{X}$ & $\mathrm{X}$ & 0 \\
\hline Management staff & $\checkmark$ & $\checkmark$ & $\checkmark$ & $\checkmark$ & $\checkmark$ & $\checkmark$ & $\checkmark$ & $\checkmark$ & 8 \\
\hline E-library Patrons & $\mathrm{X}$ & $\mathrm{X}$ & $\mathrm{X}$ & $\mathrm{X}$ & $\mathrm{X}$ & $\checkmark$ & $\checkmark$ & $\mathrm{X}$ & 2 \\
\hline
\end{tabular}

Key: $\quad \sqrt{ }=$ Applicable $\quad \mathrm{X}=$ Not Applicable

Table 10 revealed that all universities understudy are faced with financial, management staff and technological challenges. The result of this finding is not surprising because since the e-libraries were established in the same decade from the earlier findings as such the challenges they are likely to face may be the same. In addition, no university at federal and state level indicated having security challenge.

This finding tallies with that of Emwanta (2012) whose her study on challenges affecting the implication of ICT in Nigeria universities noted that the use of ICTs in university libraries is challenged with inadequate funding, maintenance and security, storage and preservation of e-resources, web based soft ware to hard ware, fluctuating of network, infrastructure, power failure, stand still or break in transmission and library management staff being affected by techno stress amongst among others.

\section{Conclusion and Recommendations}

In Nigeria the existence of the e-libraries is a current issue and managing the e-libraries is a recent development yet handled in high esteem indicating that Nigerian universities are not left out in the global trend to provide access to electronic resources to promote scholarship in teaching, learning and research.

The findings discovered that the university librarian, System librarians and Analysts are the personnel that manage the e-libraries. The study also shows that the electronic libraries are funded by the government. This finding is against that of (Rosenberg, 2005 and Bozomo, 2006) that reported dominance of international bodies as sources of funds for e-library of virtual libraries in Nigeria. The e-library users get registered to the library before they are allowed to use the e-libraries under close access they are open for a maximum of 12 hours daily. The e-libraries in the northwest zone universities in Nigeria had acquired and subscribed to a lot of e-library resources such as e-books, e-journals, databases scholarly websites, bibliographies and directories amongst others. The resources were stored in CDs, databases, websites and library portals. This finding is in agreement of Ani and Edem (2012) that there is an increased level of awareness towards the provision of electronic resources by shareholders of the university education in Nigeria. Challenges faced by the e-libraries in North West zone universities in Nigeria ranged from finance, technological, infrastructure, management staff. In the light of the findings of this study, the following recommendations are made:-

1. E-library management team should ensure the maximum utilization of the facilities especially the internet and online. These facilities facilitate quality network environment without which the e-library cannot be adequately functional. They should also collaborate with libraries within and outside Nigeria in other to share ideas on how best to manage their e-libraries.

2. Human capacity determines the effectiveness of the e-libraries hence, is the need to train and re-train system librarians and analysts who are the main staff working in the e-libraries understudy so as to meet up with current trends in information services delivery in the e-library environment.

3. Universities should not rush to establish e-libraries but send staff for training; observe other e-libraries within and outside Nigeria before embarking on the e-library project.

4. In the case of financing the e-libraries, the federal and state government should increase budget allocation (TETfund) to the libraries. Meanwhile, Northwest universities of Nigeria should avoid overdependence on the government to fund their e-library projects. They need to solicit for grants from financial institutions like banks, NGOs and other foundations. 
5. The E-library should be open access to both staff and students and offer a 24/7 day services.

6. E-library should adopt new trends in e-resource retrieval and organization as well as social media services should offered in the e-libraries.

\section{References}

[1]. Aina L.O (2004) Library and Information Science Text for Africa Ibadan: Sam Dex, Pp. 322

[2]. Ani, O. and Edem, N. (2012) Trends in the Development of Virtual Libraries in Nigerian Universities: Paper Presented at NLA@5o National Conference and Annual General Meeting Abuja. Pp.198-200

[3]. Anonubi \& Okoye (2008). The Role of Academic Libraries in Universal Access to Print and Electronic Resources in the Developing Countries: Library Philosophy and Practice2008.www://electroniclibraries/anunobi-okoye.htm

[4]. Ayo, T.A (2001). Information and Communication Technology and the Information Professional in the Information Age: A Compendium of Papers Presented at the 39th Annual Conference and AGM at Sam Mbakwe Hall, Imo Concord Hotel, Owerri 1722 June.

[5]. Bar-Ilan J. and Fink, N (2005). Preference for electronic format of scientific journal: a case study of the Science Library users at the Hebrew University. Library and Information Science Research 27: 363-370.

[6]. Batool, S. H. and Ameen K. (2010). Statues of technological competencies: a case study of university librarians. Library Philosophy and Practice retrieved from http://www.webpages.uidaho.edu/ mbolin/batool-ameen.htm on 30/01/2014

[7]. Beagle, D. (1999). Conceptualizing an information commons: The Journal of Academic Librarianship, 25(2), 82-89.

[8]. Bozomo, F. A. (2006). ICT and the Ahmadu Bello University Libraries: Nigerian Libraries 39:1-8

[9]. Creswell, N.J. (2003). Research Design: Qualitative, Quantitative and Mixed Methods Approaches $2^{\text {nd }}$ ed. Thousand Oaks, CA: Sage Publications.

[10]. Daniel, J. O. (2000). "Virtual Library for Nigerian Libraries.” Nigerian Libraries, 36(2): 56.

[11]. Ekoja, I. I (2011). Periscopic Survey of Current Library and Information Science Education and Practices in Nigeria: The Information Manager. ISSN 1596-5422. Vol. 11 (1\&2)

[12]. Emwanta, M. G. (2012). The challenges of effective implementation of ICT in university Libraries in East-Nigeria: Nigerian Libries. 45 (2) 87

[13]. Ezema, F. J. (2011). Building Open Access Institutional Repository for global visibility of Nigerian Scholarly Publications: Library Review, 60 (6).

[14]. Fabunmi B. A. (2009). Challenges and Prospects of Virtual Libraries in Universities in Nigeria: European Journal of Scientific Research (C) Euro Journals Publishing, Inc. 2009 ISSN 1450-216X Vol.33 No.1 (2009), pp.202- 208 http://www.eurojournals.com/ejsr.htm

[15]. Gbaje, E. (2007). Implementing national virtual library for higher institutions in Nigeria: Libres libraryand Information Technology journal 17(2)4.

[16]. Ibinnaye, Dorcas I. (2012) University Library Website in Nigeria: Utilization and Management. European Journal of Globalization and Development Research, vol. 4.(1) retrieved from http://www.Journalsbank.com on $23 / 02 / 2013$

[17]. Issa, A. O et al (2009). Effects of information literacy skills: the Use of e-library Resources Among Students of the University of IIorin, Kwara State, Nigeria.

[18]. Irokwe, O. P. (2001). A Blueprint for Implementing Digital Libraries in Nigerian Universities: Blueprint on the National Virtual Library Project. Federal Ministry of Education, Lagos, Section C, pp. 8.

[19]. Kumar, K (2007). Library Administration and Management: Delhi, Viukas publishing. P.2

[20]. Mabawonku, I. (2009). Training for Library and Information Profession in Nigeria: an overview of Recent Developments at the University of Ibadan Library. Paper delivered at NLA Conference and AGM.

[21]. Moahi, K H. (2009). Institutional Repositories: Towards harnessing knowledge for Africa Development: International Conference Addisa-Ababa: 1-13 July.

[22]. Mutula, S. M (2008). Local Content and African's Presence on the Web: Information and Knowledge Management in the Digital Age: Printmark Ventures, Ibadan. Pp. 61.

[23]. Ojedokun, A. A and Okafor, N. V (2011). Relevance and Adequacy of IT skills of Librarians in southern Nigeria in the Digital and Electronic Environment in Nigeria: Nigeria Library Association, $49^{\text {th }}$ Annual Conference and AGM Awka $10^{\text {th }}-11^{\text {th }}$ July. Pp. 82 85

[24]. Ojedokun, A.A (2005). The Evolving Sophistication of Internet Abuses in Africa: The International Information and Library Review, 37, 11-17

[25]. Okpara, U. N (2004). Projecting a positive Image in Nigerian Public Libraries through Public Relation: African Journal of Library, Achieves and Information Science $16 \quad$ (2), 129

[26]. Oyelude A. A. (2004) Academic Libraries the state of the art: Technology for Information Services and Management in Developing Countries: Evi-Coleman Publications.

[27]. Powell, A. (1994). Management models and measurement in the virtual library: Special Libraries, Fall 85(4), pp.260-263.

[28]. Rosenberg D. (1997) cited by Adegbore (2010) automation in two Nigerian university libraries: Library Philosophy and Practice 2010 ISSN 1522-02 22/06/2012

[29]. Sabouri, M. S., Shamsaii A. H., Sinaki J. M \& Aboueye F. (2010) Use of electronic resources by users in the faculty of Agriculture, Azad University, Middle-East Journal of Scientific Research 6(5).

[30]. Silverman, D. (2011). "Qualitative Research": Issues of Theory, Method and Practice. $3{ }^{\text {rd }}$ ed. Thousand Oaks, New Delhi.

[31]. Woherem, E. E. (2000). Information Technology in the Nigerian Banking System: Ibadan Spectrum Books Ltd. 267 